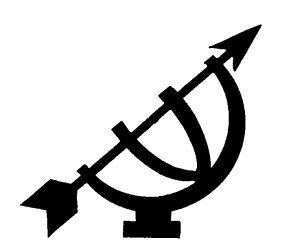

\title{
A human(e) "uni-versity": resisting scientism, technicism, and economism
}

\author{
J.J. Venter \\ School of Philosophy \\ Potchefstroom campus \\ North-West University \\ POTCHEFSTROOM \\ E-mail: filjjv@puk.ac.za
}

\begin{abstract}
A human(e) "uni-versity": resisting scientism, technicism, and economism

This article focuses on the issue of dehumanising knowledgegenerating procedures in the contemporary university. For this purpose different practical examples are analysed. It is argued that these dehumanising practices are rooted in present-day techno-scientistic elitism that has gone beyond the distinction between good and evil, and has developed into capitalistic pragmatism. Furthermore it is argued that these practices suppress critical reflection and creative alternatives in favour of gainful advantage within paradigmatic limitations. Real postmodern relativism thus does not exist; it is rather the absolutism of the economy and the market that determine the nature of knowledge-building processes.
\end{abstract}

\section{Opsomming}

'n Mensgevoelige "uni-versititeit": weerstand teen sciëntisme, tegnisisme en ekonomisme

Hierdie artikel fokus op die vraagstuk van die ontmensliking van kennisontwikkelingsprosedures binne die hedendaagse universiteit. Vir hierdie doel word verskillende praktiese voorbeelde geanaliseer. Daar word aangevoer dat dié ontmensliking gewortel is in die hedendaagse tegnosciëntistiese elitisme, wat die onderskeiding tussen goed en kwaad transendeer en agterlaat en derhalwe ontwikkel het in 'n kapitalistiese pragmatisme. Daar word aangevoer dat hierdie praktyke kritiese nadenke en kreatiewe alternatiewe onderdruk ten gunste van winsgewende voordeel binne paradigmatiese 
grense. 'n Werklike postmoderne relatiwisme bestaan dus nie; dit is eerder die absolutisme van die ekonomie en die mark wat die aard van kennisgenererende prosesse bepaal.

\section{Relativism or self-interested materialism?}

Right at the outset the following questions can be asked: Are we really living and working in a context of postmodern relativism? Or is it possible that postmodern "relativism" itself has become a handy shield for so many absolutes, usually characterised as "isms"? In this regard see Latouche's characterisation of this phenomemon:

The economy is the religion of our time. This is attested to by many analyses and recognised by certain economists themselves. Contemporary society - and many people have noted it - has not chased away idols, myths and dogmas; it has only succeeded in replacing them with others. There is in effect an abundance of such candidates for the divinity: Reason, Progress, Science, Technology - to name only the most credible. In any case the devotion to Progress, the dogma of Development, the cult of Technology, the appreciation as if sacred of Material Well-Being, up to the sacrosanct Human Rights and the untouchable Democracy, are at bottom directly or indirectly linked to the economy via utilitarianism. The calculus of pleasures and pains, of duties and rights, of costs and benefits, inhabits our projective imagination and nibbles away at the major part of our practices (Latouche, 1995:10; translation - JJV).

Over centuries we have grown into a materialistic culture of technical mastery for the sake of human advantage. If I understand Latouche correctly, this process has assumed the features of a religion, or rather an ideology that manipulates us into an understanding of rationality, such that our lives and environment are reduced to price and profit.

In the Western tradition, and until the 19th century, the defining characteristic of the human being, in comparison to other creatures on earth, was said to be man's "rationality". As will be indicated in this article "rationality" has acquired a whole spectrum of meanings in coherence with context and time. Although the concept "rationality" has always had a connection with "logic", its boundaries has never been very clear, and neither has the meaning of "logic" been. Thus from the time of Plato there was an issue about whether art can be characterised as something "rational" or as something "emotional". In Modern times Kant thought of art as "instinctive", 
while artists like Jacques-Louis David thought of it as "rational". Concerning "faith" the issue was similar - Kant identified faith with rational morality, while Lessing thought of it as largely emotional. Moral life suffered the same uncertainty: Hume and Adam Smith saw it as sentimental, while Kant made it part of a higher practical rationality. Practical life, therefore, was itself at issue: in terms of the belief in progress, practical life in its un-emancipated form was supposed to be brute and irrational, but in emancipated form to be highly rational. Believers in scientism, in turn, reduced practical life to an extension of natural scientific theory, to be engineered on the basis of quantitative observational science.

However, whether faith or art, or law or morality, has been considered to be part of the rational or not, they have always been supposed to be subject to reason's power. There never has been an indication that they may have something peculiar in themselves.

\section{Dehumanising in its different forms}

Given the fact that in some views of humanity all aspects of cultural life have been "logicised" (in terms of some specific kind of logic), and in other views they have been suppressed as being part of the brutal side of life, human life could be dehumanised in different ways:

- It could be a scientistic dehumanising, in which all aspects of practical life become modelled on the basis of the objects and methods of mathematics, physics, and biology.

- It could be a naturalistic dehumanising, in which the many aspects of human life called "irrational", would be considered as "brutal", and to be strictly controlled by "reason". Humanism has not only suffered from the "rationalistic" reduction of human life, but also from the "naturalistic" reduction: "nature" has in fact been reduced to those aspects closely associated with brute animals, so that the humanness in the human being could no more be seen.

- It could also be a rationalistic dehumanising - in this case the many aspects of especially human cultural life have been reduced to some specific kind of a priori logic, and therefore have been forced to follow the rules of such logic as far as possible. (To talk about a "rationalistic" dehumanising almost seems contradictory, since for more than two thousand years, Western "rationality" was supposed to be the distinctive characteristic of a human being. However, since the middle of the 19th century 
more and more intellectuals have expressed serious doubts as to such a characterisation, and in fact, the "irrational" element has always been present, even in rationalism. The question now is: do we have a view of the human being which is flexible and nuanced enough not to let us fall in the trap of some irrationalist reductionism?)

The issue addressed in this article is to explain how, in the course of time, both through shifts in the meaning of "rationality", and through the collapse of rationality as a result of the growth of irrationalism since the 19th century, the intellectual enterprise in the university, under conditions of the industrialising of knowledge, has become dehumanised. This process finally poses a threat to the recognition of the dignity of the human being, and it denies the pluriformity of human life even more than rationalism did.1

\section{- How the intellectual enterprise in the university has become dehumanised}

This issue will be argued by defending a number of theses - nine in total:

- A reductionist concept of rationality is progressively taking possession of contemporary global intellectual culture, limiting it to technical operation and gainful competitiveness.

- The concept of rationality as that of having mastery and advantage has been fused with an egocentric pleasuremaximising rationality.

- Technoscientism and suprascientific intellectualism have led to intellectual elitism bordering on fascism.

- The "marketable-knowledge" epistemology discourages critical evaluation and publicly absolutises the products of science.

- That competition in itself guarantees quality, is not universally true.

- The culture of learning (literacy) is dying out (inter alia) because the university has lost its sense of the calling to produce responsible intellectuals who take contextual issues seriously. 
- The belief in the saving grace of science and technology is problematic, if not dangerous.

- The conservatism of scientists noted by Kuhn, is rooted in financial and power relationships, to the detriment of sustaining a responsible intellectual culture.

- Outcomes Based Education promotes technicist training.

Technoscientism, in whatever form, in alliance with economism, puts the humane basis of the university under serious threat.

\section{The university is the house of many "reasons" Proposition 1:}

A reductionist concept of rationality - traditionally a core concept of the university's way of work - is progressively taking possession of contemporary global intellectual culture. In as far as "rationality" is still considered important, its meaning is more and more limited to technical operation and gainful competitiveness.

"Rationality" has always been at the core of the university's "business". History has produced a number of meanings for rationality, all of which

- share the idea of "structured thought processes" (procedures);

- are governed by some "values";

- are usually expressed in term of "aims" (or the "good").

The proposed procedures had as their aim the "truth" for the sake of the "good".

- The "good" has usually been aimed at the "moral" advantage of the whole cosmos, or at least all human beings.

- Central to the development of the concept of "rationality" was Hellenistic scepticism: the term "ratio" suggests that given the "untrustworthiness" of sense and emotional experience, somewhere in the understanding an innate ability exists (be it concepts, ideas, processes), to jump over the chasm between "mind" and "external world", and even see into "the mind of God". "Ratio" was therefore a construct to give the "intellect", or the "understanding" (whatever one may call the "higher" mental processes), the power that sceptics claimed it did not have. Once 
this claim was made (it had its roots in Plato an Aristotle but was really worked out by the Stoics), it became an addiction for almost two thousand years - not even the Modern empiricist, Locke, and the empiricist-sceptic, Hume, doubted the presence of such a power in the mind. And yet the concept of "reason" was never stable - in the long run it almost became an empty sound.

\section{- Variations in the use of the term rational}

One can distinguish about nine variations in the use of the term rational:

(1) The logical discovery of relative goodness leading us to the ontically absolute or ideal good - the oldest concept of rationality (cf. Venter, 1982:1-500; Venter, 1983). It was sometimes reduced to a strictly logical procedure as Hart (1977) indicates. Hart, however, neclets the instability in the meaning of "logic", due to shifts in the meaning of "rational".

(2) Non-extremist (moderate) behaviour according to the logic of finding the midway between two extremes (Aristotle, Hume, Willem de Klerk, P.W. Botha; cf. Venter, 1995:132 ff.; Venter, $1987: 1 \mathrm{ff}$.) - this variation is easily used to project oneself as "moderate", by choosing the right extremes.

(3) Gainful (usually individual) behaviour, conforming to the rules of minimising input to acquire maximum advantage in terms of the logic of calculative bookkeeping (capitalism since the Renaissance). In this respect the efficiency relationship between means and ends is of prime importance (cf. Godelier, 1972:12-17).

(4) The social(ist) counterpart of "public reason" (la raison de l'état). It has its roots in Roman militarism, re-introduced into Modernity by the Machiavellian form of Romanism, promoted by Hobbes's state totalitarianism, adopted as part of the monarchical thought of the Enlightenment, extensively theorised into a theoretical Modern absolute state in Rousseau's works, and practised terroristically during the French Revolution. Rousseau uses organismic metaphors to describe the state: the sovereign is the "head"; laws and customs are the "brain"; commerce and industry the "mouth" and "stomach"; public income the "blood"; the economy as the "heart", and the citizens the "body" and its "members". The state itself is a moral, rational being, possessing a (general) will that constitutes justice. In this way he precedes Mussolini's 
irrationalist state mysticism, for he argues that in virtuous people the heroic passion of patriotism has been made subservient to "public reason", and citizens are accustomed to viewing "individuality only in its relation to the body of the state, and to be aware of their own existence merely as part of the state" (Rousseau, 1916:252-273). Thus it is rational, by virtue of public reason, for the state to usurp the educational rights of parents, and to intervene in the economy at will. 2

(5) Well-founded (innate) common sense, following a deductive path analogous to geometry, in order to find truth that promotes the common good, by creating rigorous scientific insight into moral law, and mastering (mechanical) "nature" by techno-scientific craftsmanship based on rigorously deduced laws (Descartes; also Spinoza, Leibniz, William Petty, Turgot, the early Husserl, and others followed this line, with variations - cf. Venter, 1982:465 ff.; 1983; 2001:12-16; 22-32).

(6) Logical autonomy, arising out of "nature", yet establishing itself "above" "nature", setting the criteria and laws for itself and the universe (Kantian and Hegelian rationalism; cf. Venter, 1999).

(7) A logico-critical attitude towards every established idea reason keeps itself moving in continual critical transcending of the accepted/established, working towards the foreign, and (mystically) towards the One (Jaspers, 1952:38 ff.; Winch, 1970:99-100).

(8) Actions conforming to goal-directed rules for efficiency (the latter in the widest sense, such as the logic of effective magical ritual) (cultural anthropology - Jarvie \& Agassi, 1970:172; 191).

(9) The (Western) legal meaning, usually utilised in the context of the consequences of one's actions. A "rational" person ought to know that firing a gun in an urban area may lead to death or injury of an innocent person. In this case "rationality" is

$2 \quad$ The dialectical interplay between ( 3 and (4) was noted by Horkheimer (1978:48) in despair: "The terror which pushes reason is also the last means of stopping it, so close has truth come. If the atomized and disintegrating men of today have become able to live without property, without location, without time, they also have abandoned the ego in which all prudence and all stupidity of historical reason as well as its compliance with domination was sustained. The progress of reason that leads to its self-destruction has come to an end. There is nothing left but barbarism or freedom." 
understood in contrast to "mentally unhealthy", "mentally immature", and "mentally handicapped", and of course it is the court's problem to determine if an accused can be said to be "rational", i.e. is able to oversee the consequences of his/her actions.

\section{The historical development of the meanings attached to rationality}

The 18th century physiocratic free marketeers (discussed in the next section) fused cartesian techno-scientism and competitive gainful behaviour into one concept. Thus egocentric technical rationality has over time become the dominant meaning of "rationality", although it took two centuries for this specific ideological concept to finally dominate. This process has, however, been crossed by periods of "public reason", whether in monarchical form, or in the form of republics, including so-called people's republics, with their reigns of rationalistic or scientific terror.

When techno-scientific rationality with its hidden "strategies" for taking advantage in so-called "competitive" situations becomes the core meaning of "rationality", then the emancipation of humankind expected by the Enlightenment philosophers gets stuck halfway, or is seriously delayed. "Rationality" was, for the important Enlightenment thinkers, the basis of peace, justice, and morality. Competition was the mechanism (never the end) used by "nature" to get humankind to that utopian "rational" situation. Not surprisingly therefore, the Neo-Marxists in deep pessimism saw the emancipation project of the Enlightenment as incomplete, even floundered: unreason became the rational. Although the NeoMarxists wrote during the era of Stalinism, Fascism, and Nazism, it is as if they had seen the era of global technical economy coming (cf. for example Horkheimer, 1978:48; Habermas, 1971, especially $81 \mathrm{ff}$.; Marcuse, 1964:144 ff.).

Progressively the economy became the leading factor in social life. The state and religious institutions are thus, in the name of "freedom", bluntly told to keep their hands off the free market. Gradually the values of the market have become the values of "society".

The "good" according to the kind of "rationality" proposed by economism is the maximising of individual utilitarian self-interest (for the minimum input or "cost"). Self-interest is in this respect 
understood in the terms of "popular" hedonism (i.e. indulgence rather than the healthy sobriety of the original hedonists). ${ }^{3}$

When an intellectual community adopts this kind of rationality as its core value (whether under the name of "entrepreneurship", "competitiveness", "free enterprise", or "excellence"), its longstanding tradition of transferring a culture of communal intellectual responsibility under conditions of freedom is seriously threatened. The more "competitive" the educational or learning situation becomes, the less it becomes possible to establish a caring society, for the individual intellectual leader learns to focus on personal (or group) advantage first and foremost, and to squeeze this out of "nature" (and in the context of growing "naturalism", out of fellowhuman beings).

\section{Practical implications of this view of rationality}

Funding for intellectual institutions has been declining proportionally over the past decades.4 This declining funding creates the appearance of a competitive situation. On the one hand this situation heightens expectations of good products, and on the other hand, it institutionalises a (manipulated) survival struggle that replaces collegiality with strongly egocentric behaviour (coded as "rational"). 5 The university thus becomes just another civil utility (like a water or electricity supply company) in which the capital demands

"Hedonism" is usually defined as searching for "pleasure" and avoiding "pain", but this was traditionally not meant in the sense of partying and having orgies. The latter meaning is what I call "popular" hedonism after the analogy of the Marxist term "vulgar" materialism (i.e. materialism without a social face). Traditionally "hedonism" ("seeking pleasure") referred to leading a healthy and sober life (pleasure), and to abstaining from emotional and public involvement, as well as indulgence (i.e. avoiding "pain").

$4 \quad$ Cozzens and his friends (1990) talk of a steady state model of research funding since the 1970s, meaning that the funding since then has remained at the same level (or declined somewhat), while costs and expectations have been rising. This decline implied that the basic disciplines had to "do more with less". Especially the humanities were assumed to be able to do so much more with so much less (cf. Bunting, 1996). More serious, however, was the fact that poorer economies followed the steady state model of the richer ones, but their spending on intellectual culture steadied at a much lower proportion of GNP than the level at which the richer ones went into steady state.

5 Over centuries a whole mythology has been constructed around competitiveness: it is supposed to promote (even guarantee) good quality (even excellence), high output, economisation on input, justice, and even moral integrity. 
of competing/demanding utility suppliers ("scholarly technicians") have the upper hand over the needs of the basic sciences, and especially the requirement of methodologically highly developed hermeneutic brain power needed by the humanities and philosophy. Thus reflexivity in teaching and research is marginalised and almost completely replaced with calculative technique and specialised product. The unifying core of universal and local traditions of the academe struggles for survival in isolated pockets, and the "multiversity" enforces its presence. 6

\section{3. "Masters" of the universe?}

The "cult" of scientific technology is the upper story of the current rationality building (and its remnants in contemporary irrationalism), with the calculative, self-interested, concept of rationality as the ground floor.

\section{Proposition 2:}

The concept of rationality as that of having mastery and advantage was fused with the egocentric pleasure-maximising rationality in the nineteenth century.

"Mastery" and "advantage" is already inherent in the late Renaissance thought of Francis Bacon (1561-1626), but comes to full expression when Descartes (1596-1650) finds his basis of certainty about the laws of mechanical nature in (a priori) calculative reason itself. He believes in a divine law that demands the promotion of the general good of mankind, reached through the knowledge of the elements and the powers of the universe, thus rendering us "lords" and "possessors" of "nature" (Descartes, 1969:49) - lordship and possession after the image of the craftsman! This line of thought indeed established a fascinating connection: "lordship", "possession", "craftsmanship" - "mastery" and "ownership" by "technique".

Contemporary Western knowledge is seen as mastery, from its cradle, in many senses: it knows by making, it masters by making, it masters by owning, and by taking advantage. For Descartes this

6 A book essentail to read by anybody who wants to understand the issue of the university falling into ruins (Readings, 1996) is the work of Clark Kerr, former president of Berkeley University: The uses of the university (1963). In all naivety he gives us the "non-university", which he calls the "multiversity" - a "thing" without any kind of identity except maybe a "common grievance over parking". 
process was still aimed at the "general good"; later - as Hobbesian competitive naturalism increased its hold - the advantage of the stronger individual came to be the norm.

\section{The reduction of "nature" to its exploitable resources}

This concept of human power and control over "nature" was not limited to the abstract culture of philosophy and science. It is also inherent in the more popular culture expressed by Defoe in his fictional narrative "history" of human progress in Robinson Crusoe. Defoe, however, adds another factor: the "market"! And in Moll Flanders the Hobbesian equality of the cunning underdog female is expressd in a fascinating way.

In capitalist theory, aptly expressed in the words of the physiocrat, Quesnay (1694-1774), natural law takes a double meaning:

Natural laws are either physical or moral. By physical law one understands the regulated course of every physical event that is evidently the most advantageous for humankind. By moral law one understands the rule for every human action conforming to the physical order that is evidently the most advantageous for humankind. These laws form the ensemble of what is called 'natural law' (Quesnay, 1965:374-375; translation - JJV).

This value system which identifies physical law with advantageous events, and morality as conforming to the order of the physically advantageous, is a clear ethical rationalising of the reduction of "nature" to its exploitable resources. It provides the basis for the structuring of our knowledge-generating procedures exactly for this aim - a hidden epistemology! Note however: "nature" in "natural law" finds its basis in physical law, yet it does not exclude the human being. It rather looks at the human being from its "underside" (the subrational) to its "upperside" (the rational).

\section{The growing emphasis of an instinctively competitive, human being}

Quesnay and his physiocratic followers are well-known for their insistence on market freedom. Can we afford to forget Quesnay, an almost forgotten 18th century economist? The parallel between the physical world and the mental world with regard to human advantage is also found in Edgeworth, a well known 19th century theoretical economist and follower of Bentham's calculative utilitarian theory. This line of thought is repeated by the influential 20th century monetarist economist, Friedman. And it is still with us 
and is still used in defence of the unfettered market. (This approach is mirrored in the psychologist Maslow's hierarchy of needs.)

However, a very important aspect of the constellation of ideas about scholarship itself, both in the area of the natural sciences and the "moral" sciences, is to be found in the "giant" of the 18th century, Kant. Descartes still assumed the idea of an a priori law with a heteronomous origin, which allowed the human being technical mastery - but then mastery in application. Kant gave a different perspective: he was moving zig-zag between a naturalistic determinism at work in history on the one hand, and an autonomous imposition of the "law" on the other. Humankind is the product and puppet of "nature", yet it is also the free lawgiver of the cosmos. By "law" he had in mind both moral law as a (rational) formula, and physical law as the product of human planned experimental technique.

With regard to the natural sciences (constructing physical law) Kant (1975b:23-24) states two points very clearly:

- even natural law is somehow a product of reason;

- natural law is the conceptual product of technical planning and execution.

Kant, however, goes further: the rational technician has a special place, for only to him be the overview of history (reality) and the destiny of humankind. The scientist can and should rise above the "leading strings" of nature. The ordinary, unenlightened members of the public are on nature's "leading strings", bound like planets in their orbits (Kant, 1975a:35). Heidegger (1938:85-87) rightly understood Modernity: the omnipotent scientist sets the stage, directs the play, and plays the lead role.

Soon in the 17th century after Hobbes had presented his readers with an instinctively selfish, competitive, human being, who would eliminate the opponent in order to keep the comparative advantage, the idea of progress through conflict gained strength. Where it did not take a militaristic balance-of-powers format (as in Kant's philosophy of history), it rather assumed an economistic one. Suggestions of the overriding importance of middle-class life - as rational life! - are already present in Robinson Crusoe, and expanded to a full base-superstructure model in Turgot (anticipating Marx). 


\section{All relationships seen in terms of self-interested contractual exchange}

It was, however, Adam Smith who set the scene for liberal economism ever since. The metaphor of the self-interested individual concluding contracts is expanded to characterise all human relationships. What was meant metaphorically gradually assumed literal meaning:

- Bastiat's adage, "exchange is society" (quoted in Berthoud, 1995:63) is becoming a practical totalitarian truth, when even churches show the traits of searching for financial gain and attempting to organise themselves according to managerial techniques. And the understanding of all social relationships in terms of self-interested contractual exchange has remained with us ever since.

- The influential Austrian School of Economics stresses universal competitiveness (and is prepared to reduce issues of justice for the sake of "freedom"). This, together with the assumed parallel between physics and economics, remained in Neo-Classical theory and in Monetarism (cf. Venter, 2002a:296 ff.).

- The Neo-Liberal paradigm has subdued the doctrine of progress and substituted the doctrine of unfettered economic growth for it, yet at its foundations the belief is still that if we can get the economic base right, then the socio-cultural problems will simultaneoulsy improve.

The economic (material) base, however, has its own values to strive for, hidden in the supposed aims of an economic system. Turgot and Adam Smith saw the aims of the economic system as the creation of national wealth, but Smith defines "wealth" in terms of a hierarchy of enjoyments bought by the amount of labour commanded. At the lowest level we have the basic needs to be fulfilled, while the higher aims are in the area of comfort and entertainment: "Every man is rich or poor according to the degree in which he can afford to enjoy the necessaries, conveniencies, and amusements of life" (Smith, 1950:32).

We have to note that although Smith speaks about "every man", somehow the wealth of the nation takes precedence in his mind. The freedom of the individual is, however, needed to create such national wealth. However, the freedom of the individual is locked into an uncritically accepted class hierarchy: implicitly for the working class the necessaries, for the middle class the necessaries and 
comforts and some amusement, for the arrived nobility the necessaries, the comforts and lots of amusement.

\section{Practical outcomes of an economistic society}

In the meantime the nobility has disappeared, and the difference between middle class and underclass has also assumed regional overtones. The value system has, however, remained, and become skewed towards comfort and entertainment. The tendency towards over-consumption of both resources and luxuries, the growing earnings of gambling businesses, the speculative movements in the financial markets, and the huge salaries of sports stars, all indicate that our economistic society - especially from the side of the stronger economies on the global scene - allocates more and more resources in the direction of Adam Smith's "amusements", as well as the non-productive profiteering in financial markets (often to the detriment of weaker economies). This while the serious problems of poverty have not been solved even in the richer countries.

The ideological belief that science can solve our problems by (re)making the world through technical standardising or standardised techniques, and that what is technically possible should be done, has always gone hand in hand with the ideal of the free market, the adherents of which have ever so often chastised the state for intervention in the market, even when issues of public justice were concerned.

\section{Propositon 3:}

Technoscientism and suprascientific intellectualism lead to intellectual elitism bordering on fascism

Von Hayek (1951) indicates with great care how the adherence to the scientism of the French revolutionaries helped to devour the French Revolution. The belief that the procedures of the natural sciences are the only valid methods for the acquisition of trustworthy knowledge was the principle of transformation for the education system. Education at all levels, also at tertiary level, was reduced to training in mathematics and science by the leaders of the initial revolution. Von Hayek argues that scientism is the cradle of totalitarian collectivism, for it tends to ignore the creativity of competitive individuals. The adherents of scientism, he warns, are the over-confident know-alls: they tend to believe that it is 
scientifically possible to know what is good for all of society, and that society can be organised according to the principles of science. ${ }^{7}$

Trusting in natural science and reason in general, France was brainwashed by especially the thousands of Masonic lodges working among both the intellectuals and the poor, 8 into accepting elitist governments. The idea that those with developed rational insights had to lord it over to those who were still on the way (for the sake of the poor and the downtrodden), was founded on three beliefs:

- in the power of techno-scientistic rationality;

- in the absolute authority of "public reason" (the state as the "rational" according to Rousseau); and

- in the inevitability of progress. 9

7 I agree with Von Hayek that in Western thought a link exists between totalitarianism and the overestimation of the intellectual. George Orwell, in Animal Farm, attacks exactly this aspect of socialism. Not all proponents of intellectualism are, however, also adherents of scientism. Plato was an intellectualist and a totalitarian utopian, and so was Rousseau. But neither were adherents of scientism. Yet it is factually true that the majority of revolutionary philosophers, in particular Voltaire and the Encyclopaedists, were fascinated by the possibilities of science to create a better life. However, usually a theory of reality is also involved in authoritarian totalitarianism: organismic holism.

8 The Duc d'Antin, first leader of all the French Masons, summarised Masonic humanism in the 1740s as follows: "Human beings are essentially distinguished by the difference in languages which they speak, the habits which they follow, the land which they occupy, or the dignities with which they clothe themselves. The whole world is nothing but a great republic, of which each nation is a family and every individual a child. It is for the sake of reviving and expanding these essential maxims, drawn from the nature of humankind, that our society has been established. We want to reunite all human beings in an enlightened spirit of kind morals and friendly attitudes, not only towards the fine arts but even more through the great principles of virtue, of science and of religion, where the interest of [universal] brotherhood becomes that of all humankind, where all nations can draw on solid knowledge, and where the subjects of all kingdoms can learn to mutually appreciate one another, without renouncing their fatherlands. ... What an obligation do we not have to these superior men who, without vulgar interest, without even hearing the natural envy to dominate, have imagined an establishment of which the unique goal is the reunion of spirits and hearts to make them the best, and over time a totally spiritual nation, in which, without withdrawing from the different duties which the differences of states demand, one creates a new people which, being composed of different nations, will cement all together, in this case by the bond of virtue and of science" (quoted from Pope-Hennessey, 1911:22-23). 
Soon France had a government of dangerous know-alls, the (probably "occult" "enlightened") Jacobines - the prototype of Stalinism. The universal brotherhood preached by the Masonics, with its elitist "enlightened" leadership, ended up in an ironic medal inscripted: Soit mon frère ou je te tu. (Be my brother or l'll kill you.)

The same techno-scientistic pretence prepared the French to accept the soldier Napoleon as saviour from the Jacobines. In his technicist elitism and self-righteousness, Napoleon denigrated religion, democracy and critical thinking, and projected himself as both a Caesar and a Christ. It was easy: issues of religion, history, classical languages, justice, rights, dignity, values and quality of life had already been eliminated from education, and replaced with issues of science and technique, by the progressivist mathematician Condorcet (the education planner of the Revolution). Centralised power was stronger after the revolution than before it, says Jacques Ellul (1967: xiii-xxi).

One of the products of scientism, Auguste Comte, the father of positivism (who even supported the rise of Napoleon), in his mature years admitted that those regularities ("natural laws") disclosed for the advantage of humankind, were still meaningless without some humane centre of gravity such as "love". And then - in the face of Napoleon's technoscientism - he recovered the religion of humanity from the ashes of the revolution, in order to have a meaningful object of love (but now giving the sentiments equal status with reason).

Somehow the free-market economy proposed by the physiocrats, combined with the belief in progressive control of "nature" by science and intellect, and supported by intransparent manipulative methods ingrained by secret societies, had transformed itself into the terror of Jacobinism (first) and a military dictatorship: one "enlightened" human being playing god for others.

I would suggest that this was not a temporary deviation conducted by some egocentric militarists. It is part and parcel of the doctrine that science, rationality, and/or intellectual insight is identical to "wisdom", and occupies the position of "nature above nature". Call it the elitism of the earliest "supernatural natural" minds (the minds of the learned persons - an idea defended by Kant, Hegel, Comte, Marx and others). This elitism is still alive - if one but reads about the struggle to clarify the needs and the revolutionary mission of the under-classes in 20th century Marxism, or the foundations of apartheid as "promoting" the needs of underdeveloped ethnic 
groups, or the confusions about the rationality of non-Western cultures (mentioned in footnotes 6 and 7), or nowadays, the insistence on the free objectification of the human being by biotechnologists (cf. for example Bayertz, 1996).

\section{Marketable knowledge}

Firstly, when under situations of economism our knowing is aimed at the market, sponsored mostly by industry, the issue of intellectual property comes to the fore. We are faced with more and more patent and licensing agreements. Even graduate research outputs for the military (including Master's and Ph.D. theses) are classified as "secret".

\section{Proposition 4:}

The "marketable-knowledge" epistemology discourages critical evaluation and publicly absolutises products of science.

Understandably even educational institutions, and for sure their sponsors, will want to protect their investments. But knowledge and information acquired under intransparent circumstances and controlled by those who have financial interests in it are withdrawn from public or peer scrutiny (that already struggles to sort the corn from the chaff). Techniques developed under these conditions are practically beyond critique and reproach (and safeguarded against it by licensing), even if they are very problematic with regard to a complete and full human life. One very brief example of such a licensed technique in which the human being is detrimentally objectified is the Myers-Briggs Type Indicator, a psychometric test.

\section{Practical example: the Myers-Briggs Type Indicator}

The front page of this psychometric test tells us the following about the test:

There are no 'right' or 'wrong' answers to these questions. Your answers will help to show you how you like to look at things and how you like to go about deciding things. Knowing your own preferences and learning about other people's can help you understand where your special strengths are, what kinds of work you might enjoy and be successful doing, and how people with different preferences can relate to each other and be valuable to society. 
When this test is used - as it is often done - to determine whether a person fits a constructed profile for some or other function, it is already used as a module: it is aimed at a self-profiling; yet it is used by employers to profile their employees. A "module" is typically a piece of abstracted-abstract technique, that, when used for a purpose different from the original and intended, has a bigger chance of missing the target.

A person not licensed to apply this test is not allowed to have it in his/her possession. Requests to have it for the purpose of scholarly analysis have been ignored. But let me indicate the technological reductionism of the test. Question 9 asks:

Would you rather be considered

(a) a practical person, or

(b) an ingenious person?

It can rigthly be asked how one should respond to a question formulated thus. See the following reasons for asking this question:

- It is a principle of exegesis to take context into account. The meaning of a word is constituted somewhere in the interaction between accepted intuitions and context - in this case an important part of the context of "practical" is "ingenious", and vice versa. What are we now to assume? Since the question wants us to select one of the two, are we to take the logical basis of meaning into account in this respect, and thus infer that their mutual interrelationship is analogous to that of mutually exclusive collections? But can we truly intuitively assume that the two categories are mutually exclusive? Why should a very "practical" solution of a difficult problem not be "ingenious"? Why should I rather not want to be both "practical" and "ingenious"?

- The issues about context do not exhaust the issues of meaning in this respect. A word like practical can only be "understood" in this meagre context on the basis of the historical intuition of the respondent. What did the authors of the test have in mind? Consider the following possible aims they had: 
- Practical as in handy in a physical sense versus ingenious as in smart in an imaginative idea-constructing sense; or

- practical as in easy and cheap to do; or

- practical in the sense of giving the best possible solution, efficient for a long period, although expensive and complex?

And which of these three possibilities may not, at least sometimes, be characterised as ingenious?

- Furthermore, the third option in itself points to a further difficulty that of inductive logic in terms of time. The respondent is forced to make a generalised wish from one of two intuitively positive characteristics - he/she might wish to be both, for both seem to be positive characteristics. However, the question leaves no other possibility than to say: "I would rather always be considered 'ingenious' (as the case may be: 'practical')." An impossible generalisation about one's own wishes, because if the two are really different, should one not prefer to be considered practical in situations that demand being practical, and ingenious in situations that demand the latter?

- More fundamentally: "opposite" meanings (especially, but not only in an exclusive sense) are usually determined during the formation of a life view tradition (over a long period). They are not summarily a priori opposite in a logical sense. How can the authors of the test assume that their intuitions of the meanings of the categories are the same as those of the respondents? And if they cannot so assume, how can they be sure that they are testing what they intended to test?

- When the test is used for selection, it is interpreted against a profile. The employer (or management) will supply a profile which the person who fills the vacancy, should more or less meet. The test is formulated in futuristic terms: "how would you like to be seen?"; "what would you like to be?"; "under such-and-such circumstances what would you tend to do?", and "how would you prefer to react?" This is to be expected, since it is a selfdevelopment test. But now one is faced with oppositions such as the above. Other oppositions in the test are: "rational" versus "sympathetic", and even "merciful" versus "just". In the case of "rational" a wider context might jump into the mind of the person tested: "rational" versus "irrational". In the usual or ordinary mind state of fairly literate people, "irrational" may mean something like acting in an arbitrary way, and even mentally disturbed. In the 
legal mind acting "rationally" means something like applying your mind in terms of ordinary logic, in order to foresee the consequences of your actions, while acting in the opposite way might constitute a criminal offence.

In the tradition of liberal economic theory (from Adam Smith onwards), "rationality" has been praised as the characteristic of the mature human mind, but even such praise singers (as Adam Smith) would argue that, at least for now, one has to follow one's self-interested gut feelings, since "rationality" is too slow and indirect to be the basis of a successful individual and society. However, during the past century, the idea that "rationality" was the distinctive characteristic of being human, collapsed. Thus among managers "trusting one's gut feeling in a context of uncertainty" has taken form as a method of management (Bruère, 1987:84-102).

If the profile would be looking for a person with a good intuition, or gut sensitivity, an instinct for the interests of the organisation above all, then I do not know which choice between a constructed opposition between "rationality" and "sympathy" would help the profiler. And since the person tested has not seen the profile (and has no idea what philosophy of management lies behind the profile), such a person may for instance avoid making him/herself look "irrational" (given the other meanings of "rationality"). (Yes, there are hundreds of other questions in the test, some of which may neutralise my problematic examples. But none of us know how the profiles are weighed. And of course, if that were known, the person tested could give the answers wanted, by adjusting his/her true wishes a little bit.)

- Finally, let us be very graceful to the test, and suppose that it can give a clear indication of how the tested person would like to develop. Suppose further one candidate does not fit the profile given by the employer, and another candidate does fit the profile. Since there is no right or wrong answers, one is supposed to be honest with oneself when answering the questions. In such a competitive situation, a possibly better candidate for the job may be eliminated because he/she has not been given a good opportunity to decide if adjustment of one's wishes is worthwhile in order to get the job. (One might idealise marrying a plump redhaired woman, and end up falling in love with a skinny blonde. Very few of us are probably in the job and position we hoped for ten years ago.) If one takes into account that for some people trained in certain traditions of economic theory, "rationality" 
means "self-interested behaviour", while "gut feeling management" means the same, it may mean that an applicant may be faulted for giving the "correct" answer but using the wrong word for it.

These critical questions are suppressed because those who are licensed to possess the test, use it in the market and earn something with it. They are therefore not likely to question their own unique instruments, procedures, and methods. And those who are likely to problematise the test, are not allowed to have it in their possession!

\section{Problems of the the Myers-Briggs Type Indicator}

The problem with the test is that it ignores the "humanities" context of human meaning-interpreting behaviour. It explicitly assumes that the respondent is intuitively ready to answer the question. It remains very near to the reduced concept of meaning found in the behaviorist approach of, for example, Bloomfield - as if a word is a direct stimulus - rather than a context-networked expression of meaning - which will elicit a fairly regular (almost causally determined) response (cf. Venter, 1999c:180 ff.). However, since the test assumes machine-like stimulus-response behaviour, it reduces the tested person to an object producing apparently deterministic reactions to supposedly unequivocal stimuli. This procedure denies human subjectivity and dignity.

University training devoid of a hermeneutic and value context, produces technicians who, with the best intentions in the world, have serious problems to become humane intellectual leaders. In fact, the lack of this context lowers the quality of even technical science, for absolutised technique is bad technique, since it relinquishes itself from the sphere of responsibility. And instead of cultivating the world and emancipating the human being from toil, it becomes a divinity by projection (to use Feuerbach's term), with an extremely demanding priesthood. There is something prophetic (but ironical) in the title of Hazel E. Barnes's book of 1970, The university as the new church!

\section{Proposition 6:}

The belief that competition in itself guarantees quality is not universally true.

Secondly, the quality of marketable academic output (excellence) is supposed to be determined by its "competitiveness" in the "market". If "competitiveness" is our only criterion, we are in fact using an 
empty concept of excellence (cf. Readings, 1996:24-25). This means almost enforcing the destructive Hobbesian "comparative advantage" approach to human relationships - a permanent looking over one's shoulder to see how far ahead one is, with no goalpost this side of the grave. ${ }^{10}$ This attitude implies a severe tension, since we expect both competitive individual excellence and sharing in teamwork. Competitiveness has always been presented as a guarantor of quality, which it is not. Competitiveness does increase output, that in turn promotes standardisation. This in turn strengthens the grip of standardised techniques. Quality products may strengthen the competitiveness of an institution, but competition does not guarantee quality or efficiency.11 One rather finds a niche market in which a certain quality level is acceptable - be it high or low. Thus the competition code is strengthened through the emptiness of comparative excellence - since "quality" remains undefined, competition has no challenge for its position.

\section{The idea of competitive excellence}

In a "post-modern" relativist context, the idea of competitive excellence imposes itself with the severity of Hobbes democratised: the aims of investment (for example economic growth) justify the means by which one competes (for example pushing the weaker out of their earnings, or logging away the jungle home of the Bonobo chimps). In fact, the situation increasingly assumes the mask of Social Darwinism: eliminating the weaker is in itself fair and just, and winning in this way is in itself excellent and virtuous. Of course it is not presented in these terms: it is rather said the loser looses simply because he/she is not "competitive"! This is almost tautological.

10 Hobbes rejects all final norms; in a sense he is the first "post-modernist". Nothing is fixed; there is only empty, aimless competition: "... the felicity of his life consisteth not in the repose of a mind satisfied. For there is no finis ultimus, utmost aim, nor summum bonum, greatest good ... Nor can a man anymore live, whose desires are at an end, than he, whose senses and imagination are at a stand. Felicity is a continual progress of the desire ... because he cannot assure the power and the means to live well, which he hath at present, without the acquisition of more. ... Competition of riches, honour, command, or other power, inclineth to contention, enmity, and war: because the way of one competitor, to the attaining of his desire, is to kill, subdue, supplant, or repel the other" (Hobbes, Leviathan, 1946:63-64).

11 The prize winning biologist, Lynn Margulis, says "I am worried about the erosion of classical knowledge. People have to make news to get their grants" (Margulis, 2003:2). 
Yet humans are not simply Darwinist wild dogs who act by instinct for food. They have somewhat more sophisticated "needs", and ways to fulfil them (be the ways and needs "nice" or "not-so-nice"). Human beings are in human social relationships - friendly or inimical, with more power or less power, with stronger ethical codes or with weaker ones, subject to traditions and acquired habits or struggling against them. They can be worse than wild dogs, for they have the space of arbitrariness and the manipulative techniques to feed our dislikes.

Competition is often only a mask. Competition itself makes no decisions. Human beings decide who is to "win" and who is to "loose". The empty ethic of competitiveness (especially in intransparent managerocratic hands) easily becomes a mechanism to blame the apparent loser for losing. (This "social" competition differs widely from the controlled competitions that we find on sports fields - also see Venter [2002c:425 ff.].) The Social Darwinist principle that the loser deserves to loose is more often than not the self-justification of those who consider themselves the winners; the Machiavellian princely government, which eliminates strong coleadership finally promotes mediocracy.

In these terms, one is not excellent when he/she is not up front (wherever "up front" may be, and however he/she makes it up there). There are no defined goal posts, so the struggle goes on to the grave. In a historical reality with competitiveness as the empty norm, all we have is the struggle. Competition itself is our being and the being of our world: it is a Sein zum Tode. To "be" means "to be up front", or "to fall behind", or "to catch up". One's identity, one's self, in fact one's being in the world, is to be somewhere in the competitive hierarchy. Nothing is fixed, and our only fixed and unshared possession is our death. The record of my excellence, the curriculum vitae, is completed only in death, my only sole possession. Nobody can share in my death; only my death is my own, says Heidegger.

Standstill is death - is the naturalist adage of Hobbes. Hobbes' philosophy is surely our democratic way of livingly dying: not to grow economically is not simply to be stable, or even to stagnate, it actually implies to die! To become "mature" in the old sense of "wise", "stable", and happy with the link you could establish between your "being", your "having" and your "doing", is not possible in a purely competitive society. Culture shock - being alienated from the cultural environment to which one claims to belong - is becoming our way of life. 


\section{University, science, technique, freedom}

As already emphasised - the very structural ideals of the university academe are threatened. The university has a long tradition of freedom (that it often neglected, but a freedom to which the university could always return). The university has, for some time now, been operating in a dialectical tension with the authoritarian forces of scientism, technicism, and economism on the one hand, and the demands of the state, that constantly intervene with different excuses, on the other. At times these forces were stronger, but there was always room for resistance. It, however, remains a question whether, in the context of global economism, we can still count on this tension to keep important matters upright in the academe.

\section{Proposition 7:}

To the detriment of all intellectual work, including science and technology, the culture of learning is dying out (inter alia) because the university has lost its sense of calling.

The university tradition is one of training. Essential to the university is the presence of students. The training of students in scientific scholarship (with or without a professional focus) is to be regarded as the core task of universities: introducing students to the "wellestablished" and the "innovative" moments in the (mainly Western) intellectual tradition. This approach presupposes the active presence of certain structural elements in the university's focus, and therefore also the duty of the university to promote the good functioning of these elements.

Scholarship in the sense of "being learned" is one of the age old basic elements of the university academe. The most famous 20th century authors of textbooks in Classical languages, coming from the Oxford-Cambridge tradition, very often only had a Masters degree.12 They knew their discipline, and they knew the cultural context, visible in the examples and exercises in even a Greek grammar, for they were literate over a wide spectrum. "Being learned" - being a scholar - is the way to situate your discipline in the wider context of a cultural tradition, and to remain up-to-date with the intellectual world at large, as well as with your own discipline, for the sake of responsible scholarly training and

12 Even today in my discipline, Philosophy, the Oxford B.Phil. has more status than an Oxford doctorate. 
education. A historical perspective helps to understand foundations and the outcomes of our own work.

Yet concomitantly with the phenomenon of our entertainment society, the visual media has become dominating, and the culture of reading is diminishing fast. In public presentations one still hears quotes from Plato, Kant, or Shakespeare, but rather as "quotable quotes", decorating the presentation with apparent learning, and so discontextualised as to mean something quite different from what the borders of context would allow. Without wide literacy there is no "being learned", no "scholarship" in the deepest sense. We have become used to images that roll and jump; to fragments of worlds. There is no more staying with, or repeated revisiting, of the beloved text. Post-modernism in the arts is an exhaustion of the new, and a revisiting of the old in a contemporary electronic cloak Shakespeare can only return with pistols and large American cars. Even the old must be new - transformed into fleeting electronic images. History is only today's story. This is what the death of the reading culture says. Yesterday is today's trash can.

The liberal arts tradition as a basis for specialisation is seriously threatened by one-sided technicist professionalism in the "programme" approach of setting syllabi. Even in the United States where this format has its origins, the indications are that the traditional liberal arts model, as well as specifically majors in philosophy and mathematics, provides more competent students in professional programmes than the professional disciplines themselves are able to (cf. Blackburn, 1988:1442).

Note: those who brought about significant changes in the "natural" sciences very often had no formal scientific training, and used metaphors and even methods gained from areas of culture and the academe other than the discipline in which they excelled. High output research universities tend to suppress the possibilities to read widely and be a learned - and thus a potentially creative - academic rather than an ultra-specialist technical scientist. This situation, however, is to the detriment of technical work itself, for its limitations are no more seen. (NB: I am not denigrating technical science - just point to the suppression of its better possibilities.)

Not only is learning neglected in favour of a strictly "natural scientific" approach (scientism), combined with standardised techniques (technicism). The academe's critical function itself is suppressed! The troubles experienced by a South African natural scientist recently (as reported in the newspapers), when he exposed 
the pollution caused by the corporation he worked for, is not limited to the money-driven "private sector". Similar interest-driven sanctions have already penetrated deeply into the functioning of the university, inter alia through licensing and patent agreements, and of course also conditional sponsorships, bursaries and donations. The possible transgressions of legal or moral codes by interest groups in cases like these are probably the lesser danger.

\section{Proposition 8:}

Of much greater danger is the belief in the saving grace of science and technology by academics themselves.

"Pre-Modern" technique was very specifically geared to the needs of the individual user, made to fit like clothes. A bow was made to extend the hunting powers of a specific hunter: adjusted to the length of his arms and body, to his bodily strength, etcetera. One man's bow could not easily be transferred to another.

Modern technology has, however, its foundations in scientific abstractions and tend to take the format of general modules. This means that a contemporary technique can be applied in areas other than those originally intended for - usually overshooting or undershooting the needs of the situation. This "under-" or "overempowerment" with regard to its aims often makes contemporary technology dangerous, both in the area of its intended use, and even more in those areas where its modular generality allows notintended use.

The steadfast faith in such standardised techniques give academic consultants the self-confidence to seriously influence the personal lives of people, whether it be managerial techniques offered, or therapeutic procedures, or exploitation of resources. The consultant is more often than not the practical adherent of scientism today. And since the techniques offered are products of the entrepreneurial university, they are regarded as above criticism, for the "butchery" of the academic supermarket cannot be allowed to publicly criticise the products sold by the "groceries" section.

The critical function of a university is part of its quality. Therefore in judging a student, more and other issues should count than only technical skill. Lynn Margulis is a bit radical, but expresses the issue well in her policy of selecting post-graduate students. "I never take a straight-A student. A real scientist tends to be critical, and somewhere along the line, they had to rebel against their teachers" 
(Margulis, 2003:2). An integrated multi-faculty approach will serve the reconstruction of the university's critical function, at least as far as students go.

\section{Practical issues regarding standardised techniques}

- A student of languages will surely ask questions about the hermeneutic aspects of behaviorist, decontextualised psychometric tests. At the university where I teach, the study of languages is the task of the Faculty of Arts and Philosophy; Psychology is accommodated in the Faculty of Health Sciences; Industrial Psychology in the Faculty of Economic Sciences, and Educational Psychology in the Faculty of Education. Training programmes have been written in such a way that it is very difficult to accommodate intensive cross-fertilisation, for example to structure a debate about meaning between psychologists and linguists in spe.

- Another example: A student studying Social Anthropology may ask critical questions about the way in which a natural scientist goes about tackling the AIDS problem "simply" in a technical way, without enough sensitivity to the socio-economic and cultural contexts of the disease. Again, programmes have been written in such a way that this critical cross-fertilisation is almost impossible, and academics in the natural sciences will actively discourage and even block moves by intelligent students to do something about it. Or they will get one of their own to produce a fragment of Social Anthropology to fulfil their technical need.

Professionalist, technicist minds will object that programmes are in any case trans-disciplinary. The problem is that only technical skills are included in a trans-disciplinary way, usually uncritically in the form of very condensed course units of which the foundations are ignored. In fact, the skills and techniques are decontextualised from their root science and learnt by heart in other contexts. Undergraduate students simply learn the statistical formulas needed for psychometrics by heart, without really understanding their foundations, meaning, and limitations within the discipline of statistics. I am not arguing that they need to be able to deduce the formulas; rather that they should understand their contextual fits and misfits. Students in management and communications learn fragments of psychology as techniques to handle people, without really understanding the theoretical basis. Thus they may deny human dignity without even knowing it, simply because they do not understand the view of the human being behind the test. 


\section{The market: technicism in paradigm science and in outcomes-based training}

\section{Proposition 9:}

The paradigmatic conservatism of scientists noted by Kuhn, is rooted in financial and power relationships, and is to the detriment of sustaining a responsible intellectual culture at university level.

An economistic market orientation in science will support a strong paradigmatic "normal science" problem-solving-for-profit procedure. It tends to eliminate schools of thought, and to frown seriously about alternative approaches. Thomas Kuhn noted that "normal-science" practitioners are very conservative and aim at solving problems for which the answers are in fact already known:

Normal science, the puzzle-solving activity ... is a highly cumulative enterprise, eminently successful in its aim, the steady extension of the scope and precision of scientific knowledge. In all these respects it fits with great precision the most usual image of scientific work. Yet one standard product of the scientific enterprise is missing. Normal science does not aim at novelties of fact or theory and, when successful, finds none (Kuhn, 1970:52).

Kuhn is suggesting that the moment of "failure" in normal science is actually the creative one, on condition that the moment of surprise, the failure, is noted and followed up. I guess he suggests that the strict conditions under which normal science sets expectations makes the non-realisation of expectations noticeable. He insists that it is characteristic of science to make discoveries. But given the long life of some paradigms, I think that noticing an unexpected occurrence that appears to be a counter-example, is not the same as in fact accepting it as an anomaly. The number of uncontrollable components of even a very strictly planned experiment always leaves room to believe in the basic propositions of a theoretical construct, even if expectations do not realise. One can always say that some instrument does not measure precisely enough, or that factors still to be found are influencing the results, or that there is a minute error in the representation of certain processes. (The responses to Lavoisier's paradigm shift in chemistry may be a case in point.)

I, however, think Kuhn overlooked a possibly more serious human cause of the conservatism: a critical, paradigm-challenging 
approach threatens high output and income, since it creates suspicion about the techniques. What will happen with licensed tests or questionnaires if the foundations on which they are built are questioned? Where will our patents (entrepreneurial universities excel in these) end up if we start showing that they are not constructed on sound thinking?

If we do not, however, stimulate precisely such critical attitudes in our students, are we then really doing our duty to prepare the youth to live for more than money, or take the environment into account, or to care about those in need? When not trained to ask questions beyond problems of technical expertise, we may be preparing them for obedience to authoritarian and totalitarian control measures and policies (whether by politicians or managers), repeating the mistakes of Condorcet and the French revolutionaries (discussed above; cf. also Von Hayek, 1952; Venter, 1996:230 ff.). Furthermore, I am not sure what effect the practical example of withdrawing (marketable) knowledge from public scrutiny may have on students who want their presumably critical teachers to practise the responsible critique preached by university tradition!

The philosophy behind outcomes-based training, 13 introduced a few years ago in South Africa, and expanded over all areas of education and training, is in line with all the trends of our time. Primarily the aim of OBE is to raise the "quality", "relevance" and "costeffectiveness" of education and training for the sake of "competitiveness". Terms like "quality", "relevance" and "effectiveness" are all given economic interpretations, through the aim of "competitiveness". Cultural education is suppressed. OBE pretends novelty far beyond its merits, by contrasting itself with traditional methods of institutionalised training.

\section{Proposition 10:}

Outcomes Based Education accepts practices of "the world of work" as its aims and methods, and its values are those of economism (whether socialist or capitalist). Tensions between education and technical training will therefore be resolved by giving priority to the technical.

13 I prefer the term outcomes-based "training" to outcomes-based "education", precisely because OBE is all about "skill" and "technique", as will be shown later. 
Using Kuhn's idea of a paradigm shift, one adherent of OBE argues that "none of the traditional principles and terminologies can directly be translated, rephrased, or reworded into the outcomes-based learning context" (Olivier, 2001:2). An overstatement on two counts:

- Kuhn exaggerates "revolutionary" shifts because of his own pragmatist philosophy of knowledge and his catastrophist view of history. "Paradigm" and "incongruity of meaning" are used in the same breath, almost as a logical implication! It is overlooked that Kuhn's own prejudices are constructed into his analysis of the philosophy and history of science. Once we feel justified in using the term paradigm, we also feel justified in saying that there is only discontinuity; no historical meaning overlap at all. Therefore translation from one paradigm to another is impossible. We are so sure of the total novelty of our ideas, that we are unable to see the continuities clearly visible to others (Einstein himself - often the paradigm example of paradigm change!) who were not so charmed into a revolutionary philosophy of history. ${ }^{14}$

- OBE, it is said, is a "unique concept", "based on its own rules", which are "totally different from traditional learning". The idea therefore is that the "teacher" becomes a facilitator of the learner's self-regulated learning-how-to-learn-when-required. The learner aims at what he/she wants to achieve. Yet there is a focus, and certain skills to be mastered:

Outcomes-based learning is based on the same methodology that is formally and informally applied in the world of work to achieve outcomes. In this way the world of learning and the world of work constitute the two sides of the same coin, each describing the same phenomenon, just from a different angle. Learning the outcomes-based way enables learners to plan for intended outcomes ... It establishes abilities to prepare before executing activities, to communicate with other learners, and to assess activities and end-products. ... How can workers be expected to plan, communicate, etc. within the work context if these competencies were not adequately addressed during learning? (Olivier, 2001:2).

14 Einstein himself apparently did not know about the revolution his work was supposed to have introduced. "Es handelt sich keineswegs um ein revolutionären Akt, sondern um eine natürliche Fortentwicklung einer durch Jahrhunderte verfolgbaren linie" (Einstein, 1955:132). 
Note the terms plan, communicate, and assess. These terms are, in abstracto, the known components of scientific research method, especially with regard to teams - but also of military strategy! Why do laboratories, statistical consultants, seminar rooms and libraries exist at universities and schools? Why, in the defence force, are there operations rooms, radio communications training, shooting ranges, tank driving classes, pilot training programmes in aeroplanes, map reading exercises, and leopard crawling under barbed wire networks with live bullets flying overhead? Given these similarities, does the overstatement of the difference then imply that there is actually nothing new or special in OBE?

\section{"The world of work"}

I have found one very significant and helpful expression in the OBE line of argumentation: "the world of work". The competencies to be acquired are those required by "the world of work", at least according to the interpretation of this "world" by the designers of OBE. Again we have a clearly economistic approach, as is also indicated by terms like customer (for student), and end-product. Even though possibly metaphoric, they create an atmosphere of producing and selling - much the same as the terminology in Kerr (1963), The uses of the university (and therefore old-fashioned "Americanism"). The market orientation is clear.

The question, however, remains: is this a real paradigm shift? Is it really an approach so new that it is totally incommensurable with any existing or previous training methods, and totally untranslatable into their terms?

What further disrupts the pretence of a "unique", "totally new" approach with "totally different rules", is exactly the admission that this is the same methodology that we find in the world of work (and it is even said that this is also the way in which we organise our lives (Olivier, 2001:3). OBE therefore seems to be a generally applied, age old, universal, yet unique, totally new, method of acquiring knowledge - indeed a superb contradiction!

However, mentioning "the world of work" directly demonstrates the technicist basis of OBE. Granted, the techniques included in the policy of OBE are a bit wider than we should usually expect in this kind of approach (e.g. the inclusion of "communication"). But since the planning of the educational content is determined backwards from the point of outcomes wanted by the learner, one is left in the lurch about how far the "backwards" determination is supposed to 
go. Are we going back only to the most essential techniques required by the world of work, or, for example, as far back as the explanatory basis?

Do I, for example teach psychology student statistical techniques with their direct explanatory contexts (know why), or exactly without it (as pure know how)? Or do I even transcend the direct context, and proceed deeper to the philosophical basis, which justifies or conditions this statistical analysis? OBE is supposed to induce critical thinking, but is this wider than the assessment desired in the production line?

The practice of $\mathrm{OBE}$, in terms of the programmes already approved by SAQA, and especially in combination with the absolutising of professional training (now often for newly invented "professions"), is almost purely technical, whether so intended or not.15 And purely technical specialist programmes are exactly not the kind of programmes that one needs in an era when more and more people do not work in their specialisation(s) for longer than ten years!

Talking of the "world of work" in the same breath as "costeffectiveness," exposes a serious dilemma of technicist training. OBE as explained in this article is well-known under another name: in-service training! The concept of OBE is therefore almost as old as the oldest apprenticeships are. Ivan Illich devoted two whole books to this issue, emphasising the advantages and cost-effectiveness of ridding ourselves of entire institutional training systems in favour of apprenticeships with the best "master craftsmen" in the field (cf. Illich, 1972; 1974). His sense of direct effectiveness in technical training is correct to a certain extent: To change traditional institutional education into a form of "in-service" training is simply impossible in any institutional form of training, because one is instructed to take into account the individual learner's preferred outcomes, and his/her self-control of learning, as well as that of the rest of the class - as individuals! (If this is ever to become a communal learning experience, it will have to be done in very small group settings.)

15 In the case of the university where I work, it has become an excuse for the Faculty of Education to eliminate training in disciplines almost totally from their programmes. This means that one does not need a high level of training in English literature and grammar, as taught at a university department of English, in order to qualify in the Faculty of Education as a teacher of English. All the knowledge needed is supposed to be integrated in the professional training. 
- Engineering laboratories at universities and technical training facilities are simply different from a real workshop.

University engineering laboratories in South Africa are mostly far ahead of their counterparts in the private sector, but they are not production facilities as such. But for those who enter the brain drain, our university facilities prove to be far behind those in the richer countries. In some poorer countries (as in central Europe), maintaining laboratories are too expensive for universities, and highly qualified natural scientists are furniture salesmen. This situation is costly, because these highly skilled people become part of the brain drain by emigrating overseas. Another possibility for these highly skilled people is to move into management positions, where it takes them a long time to develop the necessary human skills, and often also a minimal feeling for the imaginative side of being a designer.16 And of course the issue of economic strategy still prevails: where does the employment of the engineer comes from? In a more Keynesian (activist) approach and from the side of the state, engineers may be consultants for state capital projects, but if we have a monetarist or neo-classical view, or the state has an inability to spend its budget, we shall have an increase of the brain drain, or the unemployment of technologists (see for example Van Rooyen, 2003).

In spite of these obvious problems (especially the limited bridgeable distance between the worlds of "study" and "work"), even postgraduate students in the human sciences are now trained (and prefer to be trained) as pure, specialist technicians. The high output of good technical research creates the impression of overall "excellence" (again the competitive, empty excellence), but the training does not encourage meditative, reflexive maturation. ${ }^{17}$

The training of students is focused on producing results (very often measured data) in the shortest possible time. The question "What am I doing and what is the meaning of what I am doing?" is swept under the carpet. The need to read wider than the specific discipline or even the project is smothered, and the perspective of where my

16 Significantly some influential "managerocratic" guru books have been written by ex-engineers, who do not seem to clearly distinguish machine processes from human organisational life. Presently the emphasis in these disciplines falls on innovation, which is not the same as creativity.

17 A university is essentially a philosophical institution in the widest sense of the word, says J. Chr. Coetzee (1954:9). 
work may fit into the world is left to philosophers and theologians, working somewhere in the margins. ${ }^{18}$

- Small group training - the nearest to individualised training an institution can offer - has already become almost impossible.

We are in a phase of speedy output, mass education combined with "right sizing", "down sizing", and "rationalisation" - or whatever learned term one uses to cover the diminishing of staff and infrastructure. Post-graduate degrees are coming at a very fast rate (and in some cases standards are visibly falling) in the context of research-training structures, such as focus areas, of which the nearest analogue is the industrial assembly belt.19 "Interactive" ("talking to oneself") study guides can give the student some support, and computer-based training can ease the burden, but neither study guides nor computers can inspire the student, nor introduce her/him to the quality tradition of the area of study. Quality is really not measurable outside a consensus about minimum standards. It is rather a tradition established over a long time.20 The human teacher is irreplaceable. And although Horkheimer characterised the lecture as a failed secularisation of the sermon (since it is not dialogical), 21 even a good lecture can set a model and inspire a student.

18 The plea of Horkheimer has been losing its voice: "Uberall über die eigen Fach hinauszublicken, sich nicht als Arzt oder Jurist oder Historiker in seinem wissenschaftliche Interesse zu verhärten und stumpff zu machen gegen das Leiden des Menschen, am Ganzen teilnehmen, der Grenzen des Expertentums bewusst zu sein, und doch unermüdlich in seinem Fach besser werden, dass ist die Aufgabe" (Horkheimer, 1953:7).

19 The term, "industrial assembly belt", is seriously meant - and not witty, sarcastic or ironic.

20 A double edition of Time (2001, August p. 20, p. 27, under the title "The quest for quality: why Europe's craftsmen are still the best"; see Anon., 2001) has been devoted to the arts and crafts tradition of Europe. The journalists concluded that these arts and crafts have survived centuries of technological mass production, because of their quality tradition. Still, the scientistic technological tradition of testing and quantifying "quality" had the arrogance to test Dutch clogs to determine whether they fulfil the requirements of European health and safety standards!

21 Die akademische Vorlesung ... ist eine misglückte Säkularisierung der Predigt. In der Form des akademischen Vortrag liegt beschlossen die Autorität der Lehre ... (Horkheimer, 1953:24). 
- Establishing a link between the "world of work" and the "world of study" is a difficult task, especially when one engages in specialist technical training.

One may attempt to base the link on "marketability", but the market is fickle and highly unpredictable (and not nearly analogous to predictable physical processes, as economists want us to believe). Although the natural sciences and technology are supported by government for the sake of competitiveness, it is often difficult for university graduates in this area to find work.22 The more "programmed" and "focused" our training is, the less options the trained person actually has. One cannot but suggest that a somewhat wider training may complement specialist training in such a way that either the graduate is prepared to find employment in a spectrum of related areas, or is able to re-school in a short period.

- We must develop OBE techniques for the situation where it works best: in-service training

It will be wise to adopt some of the techniques for institutional training, for example closer contact with the work situation. This can, however, only be done if the private and the public sector are geared to accommodate students for internships, and training institutes are prepared to set their calendar not according to the needs of rugby and hockey, but according to academic needs (specifically the relationship between the world of study and the world of work).

\section{Practical example:}

It should, however, be remembered that even purely specialist, technical in-service training is not safe against the instability of the market. Where technology is well developed, such as calculative technology and the automatic transfer of homogeneous goods, it replaces highly skilled but very specialised human beings. An example of this is the banking and financial sectors. Cashiers in banks and bookkeepers are replaced by machines. Transaction speed increases, and profits or savings grow. Service quality, however, declines, since one cannot explain a problem to a 
machine. In fact the use of facilities under direct human control is discouraged by price differentials. The only option for young people who train at work, is to ask to be shifted to another department as soon as they have mastered the skills of any one section, in order to gain experience in all sectors. But universities cannot provide for such rotation in their training structures. However, the recent corporate scandals indicate that even if they could, we should still have to train business graduates and technical experts in ethical principles, as well as a hermeneutics of suspicion, rather than aiming at perfect technical skills. It is, however, our best tradition to broaden the scope of training by making it human-sensitive, "artistic", and "philosophical".

\section{An utilitarian production ethic}

In the case of OBE, the value system is determined by its focus on "the world of work". This focus implies that the values are set by the aims of production. These latter aims again are determined by international competitiveness - a utilitarian production ethic. "Relevance" usually has a wide meaning - more or less "that which has a distinguishable connection with something important". When one, however, talks of "relevance" in the context of OBE, its meaning is squeezed into the utilitarian funnel of "the skills demanded by the work situation" or, "... by the labour market", or simply: " $\ldots$ by the market itself". Thus the shift in market values away from needs to consumerism (Adam Smith's "comforts") and entertainment (Smith's "amusements"), will co-determine the aimside values of OBE: we shall finally end up in the popular hedonist form of utilitarianism, for the pace makers in the market determine the issues that are addressed in market terms, as well as the price structure, and the type of products focused on. The "law" of "supplyand-demand" is a complex norm, not a "natural law", and works through human agency and power relationships.

\section{Bureaucratic controls}

The OBE interpretation of utility is clearly strongly focused on the technically necessary. SAQA is already quite authoritarian in enforcing a very high technical skills content into new programmes, to such an extent that one can almost not find slots for even a minimum of fundamental critical disciplines. Like SAQA, so are the professional associations. They monopolise the registration of practitioners, and enforce tight technical programmes. And the government's one-sided support for technical knowledge throttles the human sciences and the basic sciences even more. All this is 
subject to strict bureaucratic controls (local, national, international) not only through prescriptions about programmes and methods of assessment, but also in terms of the universal audits. 23 These audits tend to quantify "quality" and/or "excellence" in terms of means available for aims, and aims in terms of output desired, as well as in terms of the comparative position with regard to aims realised and output produced. Is this situation perhaps an illustration of Hobbes returned?

No criteria are provided by which to decide whether the aims are meaningful, since post-modern pragmatists recognise no norms that specify the character of an institution. The means-aims proportion has finality; there are no further criteria to determine whether the means are justifiable. Together with the adherence to the competitiveness code, such an approach can easily lead to the justification of the means by the ends themselves. ${ }^{24}$ And it is not surprising that an authoritarian approach develops, for how can excellence be determined comparatively without enforcing a large measure of conformity to bureaucratic aims (i.e. workplace demands as understood by the civil managerial elite)? Otherwise "donkeys" will be compared with "jumbo jets".

That section of academic freedom and institutional autonomy where critically creative innovations takes place, has to a large extent been

23 The audit has its roots in the contermporary belief that achievement can be adequately measured in quantitative terms, and therefore, in a market-driven context, this measurement has to be done in terms of cost versus output translated into money terms. Bureaucrats have extended the term "audit" to include various aspects in the equation, but the process remains in the tradition of quantifying, and comparative determination of competitive position (cf. Davis, 1999; Readings, 1996:24 ff.).

24 The international audit of the Potchefstroom University conducted by the Committee of Rectors of European Universities would have delivered no insights if it were not that PU staff used the opportunity for anonymous criticism. The Committee could not give any circumscription of "academic quality" or "excellence", except in terms of vague and very incoherent references to "clients" and "market" and "peers". They did criticise "in-breeding" on the grounds that too large a percentage of the academic staff received their doctorates from the North-West SUniversity itself. Their view represents a quantified criterion of inbreeding, which does not take into account any content: the majority of strong internal critics also obtained their doctorates locally, while a large number of those who came from "elsewhere" - key appointments by management to make sure that the philosophy of techno-scientific economism and managerialism is implemented, are quite uncritical. The auditors themselves then belong to the in-bred: they have been carefully selected to support the pragmatist philosophy imposed by management. 
eliminated or neutralised by OBE principles, programme structures, and utilitarian market demands. Valuable academic time is consumed by filling in applications, evaluation forms, output reports, feedbacks, budgets, or formulating impossible aims and outcomes to satisfy politicians and management. In practice: to satisfy the enormous bureaucratic machinery (that has to develop information systems, assessment techniques, evaluate and approve). 25

\section{A few concluding remarks}

\section{- The university was originally founded on the concept of "rationality"}

The university was erstwhile founded on the concept of rationality, as the characteristic of a sensible human being, and even that which the human being shared with God. Rationality, with its array of meanings centred in evaluative thinking according to logical rules, has, however, been reduced in contemporary times to technical mastery (especially of a calculative nature), and gainful competitiveness. Intellectual communities that take these as their special values, tend to train self-centred or group-centred intellectual leaders, rather than socially caring ones.

\section{- The concept of rationality as having advantage and mastery}

The concept of rationality as having advantage and mastery, fused with egocentric pleasure maximising rationality (the format that competitiveness finally took), was embedded in the humanist belief that through this interpretation of being human, we could be masters and possessors of "nature", in the fashion of the master craftsman. It came to mean that through science and practical rational action, human rationality has the ability to impose the law unto "nature". The belief itself that rationality is the distinctive characteristic of being human has, however, been seriously compromised. Thus the values

25 Even senior staff with good academic records have to undergo constant evaluations by their managers. Would that those managers read Fichte: "Man studiert ja nicht um lebenslänglich und stets dem Examen bereit das Erlernte in Worten wieder zu geben, sondern um dasselbe auf die Vorkommende Fälle des Lebens anzuwenden, und es so in Werken zu verwandlen ...; es ist den nach auch hier letzten Zweck keineswegs das Wissen, sondern vielmehr die Kunst das Wissen zu gebrauchen" (Fichte, 1956:7). Whereas at the Potchefstroom campus of the North-West University the "support" staff number twice the academic staff, support staff directly available for academics has dwindled, following the advice of a mathematician consultant who determined mathematically how many academics ought to do with one secretary. 
by which our young people live are determined by enjoyment and entertainment, based on the appropriation by their parents. Respect for the "object" of mastery, "nature" (which according to some people includes the human being), is diminishing fast. (In fact one could see the New Age forms of pantheism as a reaction against this exploitative Modernity; which, together with the fear of Communism and Islam, pushes the Christian rightwing even further in a direction to the advantage capitalism and militarism).

\section{- The importance of the intellect}

The intellect, including its rational function, always had primary importance in Western culture. It is a great irony of history that the logic of Modern autonomous reason emancipating from "nature", implied Jacobinism and Napoleon's techno-scientific dictatorship. Enlightenment became "authoritarianism". Implicit in the technoscientific epistemology is the belief of techno-scientists that they are themselves the elite who have to emancipate others, whether using liberal (competitive), or collectivist (Jacobinist or Communist), or dictatorial means. Although each of the three are vying for primacy, the real issue, underlying all three, is the power of techno-scientism as applied in the context of economism and a hedonistic lifestyle.

\section{- The marketable knowledge epistemology}

The marketable knowledge epistemology discourages critical evaluation and publicly absolutises products of science, as means of control over the lives of human beings. This point of departure is applied over a broad spectrum: from the making of weaponry, through biotechnology to psychometric testing. It even applies to the ideology of competitiveness, which has itself become a technique for control and enforcement of the managerial will.

\section{- Competitiveness does not guarantee quality}

One of the myths at the basis of the belief in competitiveness is that it guarantees "quality" or "excellence". Competition itself does not universally guarantee quality. (Sometimes it may even be the other way round: within market niches quality may guarantee competitiveness.) Competition - that is, the type of competition we supposedly find in the market - is rather about elimination of the opposition. (This approach is not analogous to competition in amateur sports.) It is not "competition" that decides who wins. There are human beings behind the masks of competition who do make decisions about winning or losing. 
"Benchmarking" and "excellence" are in themselves no criteria for a university. Social Darwinism is in itself impractical: even Hobbes saw the warlike "state of nature" as a dangerous hypothetical alternative, which he used to defend the absolute authority of the British king. Competitive quality determination in academic work is not determined according to output, which changes the quality issue into a quantity issue, for this is the only way in which management can hold onto control in terms of the doctrine. (Note the glut in academic journals, irrelevant information, and now an overload of researchers with doctoral degrees, who cannot find work; cf. Brahic, 2004.)

\section{- The university governed by capitalist technicism has lost its sense of calling}

The culture of university learning is dying out to the detriment of science and technology, since it robs technique of its socio-cultural and moral content. The university governed by capitalist technicism has lost its sense of calling: to train students the skills of critical, evaluative analysis; an ability that does not assume that a technique is good and safe just because it has been patented, licensed, and internationally accepted. Moreover, there are clear indications that a liberal-arts basis for the professional programmes improves the quality of the professionals.

\section{- Technicism and managerialism erode "human dignity"}

The belief in the saving grace of science and technology neglects their abstract modular character. This is to the detriment of "nature" and humankind. Technicism and managerialism are eroding "human dignity", and since the university has become the victim of both, the wrong example is being set to students.

An important example is Outcomes Based Education, since this is the basis of present-day education. But it has completely fallen into the trap of technicism. It therefore over-accentuates its own newness: the importance of practical application dates (at least) from the Renaissance. It in fact seems not so much more than what has for decades been called "in-service training", except that now we want it done at educational and training institutions. The problem is that the ability of such institutions to simulate the actual work situations is very limited (even in institutions of a highly technicised nature). 


\section{- Creativity is suppressed to conserve the paradigm}

Creativity, which goes much further than innovation, will be suppressed for the sake of conserving the paradigm. Finally the technicising of science and scholarship ends up in the dialectics of paradigmatic conservatism and innovationism. Creativity, which goes much further than innovation, will be suppressed for the sake of conserving the paradigm, but behind the screens the conservatism is determined by materialistic gainful advantage.

\section{List of references}

ANON. 2001. The quest for quality: why Europe's craftsmen are still the best. Time: 27, 27 Aug.

BARNES, H.E. 1970. The university as the new church. London: Watts.

BLACKBURN, S. 1988. NB: the government, the universities and philosophy. Times Literary Supplement, 4(474):1442-1453.

BAYERTZ, K.1996. Human dignity: philosophical origin and scientific erosion of an idea. (In Bayertz, K., ed. Sanctity of life and human dignity. Dordrecht: Kluwer. p. 73-90.)

BRAHIC, C. 2004. French science jobs reinstated: campaign to save research wins a battle, but scientists say the broader fight goes on. The Scientist: News Journal for the Life Sciences, April 4. htpp://www.thescientist.com. Date of access: 4 Apr. 2004.

BRUĖRE, E.G.J. 1987. Van eiebelang tot onsekerheid: wysgerige grepe uit die geskiedenis van ekonomiese denke. Potchefstroom: PU vir $\mathrm{CHO}$. (M.Com.-verhandeling.)

BUNTING, B. 1996. Revising higher education policies. Bulletin: News for the Human Sciences, 3(1):1, 12.

COETZEE, J. Chr. 1954. Ons Universiteit: sy grondslag en beginsel en die vryheidsbeginsel. Koers, 21(6), Bylaag:1-12.

COZZENS, S.E. et al. 1990. The research system in transition. Dordrecht: Kluwer.

DAVIS, J. 1999. Administering creativity. Anthropology Today, 15(2):4-9.

DESCARTES, R. 1969. A discourse on method: meditations on first philosophy: principles of philosophy. Transl. by J. Veitch \& A.D. Lindsay. London: Dent.

EINSTEIN, A. 1955. Mein Weltbild. Hrsg. von Karl Seelig. Frankfurt-a-M: Ullstein Bücher.

ELLUL, J. 1967. The political illusion. Transl. by K. Kellen. New York: Random House.

GODELIER, M. 1972. Rationality and irrationality in economics. Transl. by B. Pearce. New York: Monthly Review Press.

HABERMAS, J. 1071. Toward a rational society: student protest, science, politics. Transl. by J.J. Shapiro. London: Heinemann Educational Books.

HART, H. 1977. The impasse of rationality today: a précis. (Typed and photocopied.) Toronto: Institute for Christian Studies.

HEIDEGGER, M. 1938. Die Zeit des Weltbildes. (In Heidegger, M. Holzwege. Frankfurt a. M.: Klostermann. p. 68-104.) 
HORKHEIMER, M. 1978. The end of reason. (In Arato, A. \& Gebhardt, E. The essential Frankfurt school reader. Oxford: Blackwell. p. 26-48.)

JARVIE, I.C. \& AGASSI, J. 1970. The problem of the rationality of magic. (In Wilson, B.R., ed. Rationality: key concepts in the social sciences. Oxford: Blackwell. p. 172-193.)

JASPERS, K. 1952. Reason and anti-reason. London: SCM.

KANT, I. 1975a. Idee zu einer allgemeine Geschichte in Weltbürgerliche Absicht. (In Weischedel, W., Hrsg. Kant: Werke in zehn Bänden. 9. Darmstadt: Wissenschaftliche Buchgesellschaft. p. 33-50.)

KANT, I. 1975b. Kritik der reinen Vernunft. (In Weischedel, W., Hrsg. Kant: Werke in zehn Bänden. 3. Darmstadt: Wissenschaftliche Buchgesellschaft.)

KERR, C. 1963. The uses of the university: the Godkin lectures at Harvard University. Cambridge: Harvard University Press.

LATOUCHE, S. 1995, Avant-propos. (In Latouche, S., ed. L'économie devoilée Paris: Editions Autrement. p. 15-36.)

MARCUSE, H. 1964. One-dimensional man: studies in the ideology of advanced industrial society. Boston: Beacon.

MARGULIS, L. 2003. First Person: Lynn Margulis. (Interview). The Scientist, 17(13):30. http://www.the-scientist.com/yr2003/jun/upfront 4030630.html Date of access: 5 Jul. 2003.

OLIVIER, C. 2001. Let's educate, train and learn outcomes-based. Ifafi: OBET Pro.

POPE-HENNESSEY, UB. 1911. Secret societies and the French Revolution, together with some kindred studies. London: Bodley Head.

QUESNAY, F. 1965. Le droit naturel. (In Oncken, A., ed. Francois Quesnay: ouevres économiques et philosophiques, accompagnées des éloges et d'autres travaux biographiques sur Quesnay par différents auteurs. Aalen: Scientia. p. 359-377.)

READINGS, B. 1996. The university in ruins. Cambridge: Harvard University Press.

ROUSSEAU, J.-J. 1916. The social contract; the discourses. Transl. by G.D.H Cole. London: Dent.

SMITH, A. 1950. An enquiry into the nature and causes of the wealth of the nations. London: Methuen.

VAN ROOYEN, D. 2003. Staatsgesloer skep ingenieurskrisis. Rapport Internasionale Nuus (Nuusfokus): 6, 26 Jan.

VENTER, J.J. 1982. Geloofsgebonde denke by Anselmus: 'n studie van sy wysgerige metode. Potchefstroom: Potchefstroom Universiteit vir $\mathrm{CHO}$. (D.Phil.-proefskrif.)

VENTER, J.J. 1983. Rasionaliteit by Anselmus van Kantelberg. Humanitas (HSRC), 9(1):1-14.

VENTER, J.J. 1987. Samelewingsverandering in die Kairos-dokument. (In Van der Walt, B.J., red. 'n Reformatoriese kommentaar op die Kairosdokument. Potchefstroom: IRS. p. 39-53. Wetenskaplike Bydraes van die Potchefstroomse Universiteit. Reeks F1, nr. 231-232.) Also available in English: VENTER, J.J. 1988. Transformation of society in the Kairos Document. Orientation, 48:104-118.

VENTER, J.J. 1995. Ontologie, representasie en metode. (In Viljoen, H.M., red. Metodologiese implikasies van enkele representasie-opvattings vir literatuurstudie. Pretoria: RGN. p. 129-228.) 
VENTER, J.J. 1996. Conceiving conflict/competition - gripped by a worldpicture: C. Darwin, D.H. Lawrence, F.A von Hayek. (In Tymieniecka, A.-T., ed. Analecta Husserliana, 48. Amsterdam: Kluwer. p. 205-248.)

VENTER, J.J. 1997. Mechanistic individualism versus organismic totalitarianism: ultimate reality and meaning. Interdisciplinary Studies in the Philosophy of Understanding, 20(1):41-60.

VENTER, J.J. 1999a. "Modernity": the historical ontology. Acta Academica, 31(2):18-46.

VENTER, J.J. 1999b. H.F. Verwoerd: foundational aspects of his thought. Koers, 64(4):415-442.

VENTER, J.J. 1999c. The role of philosophy in a reformational Christian university. Tydskrif vir Christelike Wetenskap, 35(3 \& 4):163-200.

VENTER, J.J. 2000. How worldviews germinate: genesis versus the occult worldviews. Tydskrif vir Christelike Wetenskap, 36(1 \& 2):37-76.

VENTER, J.J. 2001. Early modern conceptions of "natural law". Acta Academica, 33(2):1-39.

VENTER, J.J. 2002a. Economism: the universality debate in orthodox economics. (In Tymieniecka, A.-T., ed. Analecta Husserliana: the year book of phenomenological research. Vol. 76. Dordrecht: Kluwer. p. 89320.)

VENTER, J.J. 2002b. "Nature", "law", "humanity": the rise of positivism, with reference to Quesnay, Turgot, and Comte. Acta Academica, 34(1):1-55.

VENTER, J.J. 2002c. On nature, culture and competition: a critique of European culture. (In Actas de I Congresos "Cultura Europea", Pamplona 25 al 28 du octobre de 2000. Editas par Enrique Banus y Beatriz Elio. Navarra: Thomson/Aranzadi/Universidad de Navarra, Centro de Estudios Europeos. p. 425-436.)

VENTER, J.J. 2004. Human dignity and the objectification of the human being. (In Tymieniecka, A.-T., ed. Analecta Husserliana: the year book of phenomenological research. Vol. 79. Dordrecht: Kluwer. p. 537-601.)

VON HAYEK, F.A. 1952. The counter-revolution of science. Glencoe: Free Press.

WINCH, P. 1970. Understanding primitive society: the problem of the rationality of magic. (In Wilson, B.R., ed. Rationality: key concepts in the social sciences. Oxford: Blackwell. p. 78-111.)

\section{Key concepts:}

competitiveness versus innovation

dehumanising - issue of

managerialism

scientism

technicism

university: core task 


\section{Kernbegrippe:}

besturokrasie

kompeterendheid versus innovering

ontmensliking - vraagstuk van

sciëntisme

tegnisisme

universiteit: kerntaak 